\title{
ИЗУЧЕНИЕ ВЛИЯНИЯ ЭПОЭТИНА АЛЬФА, РОЗУВАСТАТИНА И ИХ КОМБИНАЦИИ НА КРОВОСНАБЖЕНИЕ КОСТНОЙ ТКАНИ ПРИ ОСТЕОПОРОЗЕ И ПЕРЕЛОМАХ НА ЕГО ФОНЕ
}

\author{
П.П. Ремизов, О.С. Гудырев \\ ФГАОУ ВО «Белгородский государственный национальный исследовательский \\ университет»
}

DOI: 10.19163/MedChemRussia2021-2021-463

E-mail: gudyrev@bsu.edu.ru

Эксперименты проводили на 240 самках крыс линии Wistar массой 200250 г. Манипуляции проводили под наркозом (хлоралгидрат в дозе 300 мг/кг внутрибрюшинно). Экспериментальные животные были разделены на 12 групп, по 20 крыс в каждой группе: I - «интактные» - ложная операция овариэктомии; II - «контроль» - овариэктомия; III - овариэктомия, эпоэтин альфа 50 ME/кг п/к один раз в неделю на 9-12 неделях; IV - овариэктомия, розувастатин 0,86 мг/кг в/ж ежедневно на 9-12 неделях; $\mathrm{V}$ - овариэктомия, эпоэтин альфа + розувастатин; VI - овариэктомия, стронция ранелат 171 мг/кг в/ж ежедневно на 9-12 неделях; VII - ложная овариэктомия, через 8 недель перелом бедра; VIII - овариэктомия, перелом бедра; IX - овариэктомия, перелом бедра, эпоэтин альфа 50 ME/кг п/к один раз в неделю на 9-12 неделях; $X$ - овариэктомия, перелом бедра, розувастатин 0,86 мг/кг в/ж ежедневно на 9-12 неделях; XI - овариэктомия, перелом бедра, эпоэтин альфа + розувастатин; XII - овариэктомия, перелом бедра, стронция ранелат 171 мг/кг в/ж ежедневно на 9-12 неделях. Моделирование переломов бедра производилось закрыто, с последующей интрамедуллярной фиксацией спицей Кишнера. На 85 день после овариэктомии у животных измерялся уровень микроциркуляции в костной ткани проксимального метафиза бедра (группы I, II, III, IV, V, VI) или в костной мозоли (группы VII, VIII, IX, X, XI, XII). Параметры микроциркуляции оценивали лазер-допплеровским флоуметром Biopac systems MP150 с датчиком TSD144.

Обнаружили, что в группе «интактных» животных уровень микроциркуля-

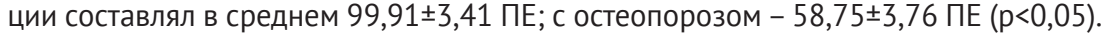
Введение эпоэтина альфа, розувастатина, их комбинации достоверно повыша-

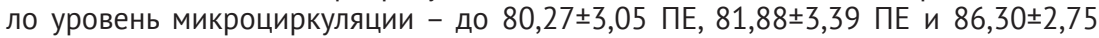
ПЕ, соответственно, в отличие от животных с введением препарата сравнения - 67,48 2,98 ПЕ (p=0,077 по сравнению с контролем). На модели экспериментальных переломов уровень микроциркуляции в костной мозоли у крыс без

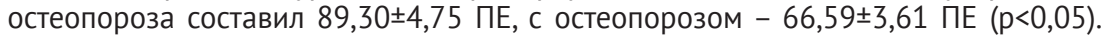
У крыс, получавших эпоэтин альфа, розувастатин и их комбинацию, кровоснаб-

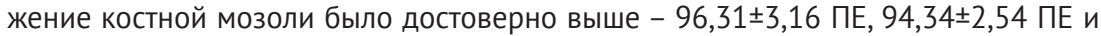
$101,05 \pm 2,75$ ПЕ, соответственно, в отличие от крыс, получавших стронция ранелат

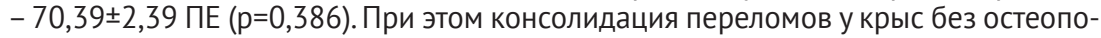
роза наступала в $75 \%$ случаев, у крыс с остеопоротическими переломами - в 55\% случаев, при терапии консолидация наступала в 100\% случаев. 